\title{
Analysis of Climate Variability, Perceptions and Coping Strategies of Tanzanian Coastal Forest Dependent Communities
}

\author{
J. J. Kashaigili1 ${ }^{*}$, P. Levira ${ }^{2}$, E. Liwenga ${ }^{3}$, M. V. Mdemu ${ }^{4}$ \\ ${ }^{1}$ Faculty of Forestry and Nature Conservation, Sokoine University of Agriculture, Morogoro, Tanzania \\ ${ }^{2}$ Tanzania Meteorological Agency, Dar es Salaam, Tanzania \\ ${ }^{3}$ Institute of Resource Assessment (IRA), University of Dar es Salaam, Dar es Salaam, Tanzania \\ ${ }^{4}$ School of Urban and Regional Planning, Ardhi University, Dar es Salaam, Tanzania \\ Email: ${ }^{*}$ jkashaigili@gmail.com
}

Received 16 January 2014; revised 12 February 2014; accepted 7 March 2014

Copyright (C) 2014 by authors and Scientific Research Publishing Inc.

This work is licensed under the Creative Commons Attribution International License (CC BY).

http://creativecommons.org/licenses/by/4.0/

(c) (i) Open Access

\section{Abstract}

Climate variability and change are among the biggest challenges of the $21^{\text {st }}$ century. Like in many other areas globally, the coastal communities of Tanzania have always been facing climatic variability at various time scales. Using focus group discussion and a household survey, this study analyzes the perceptions of climate variability and change and the strategies for coping and adaptation by the selected coastal rural and peri-urban communities in Tanzania. The perception of climate variability and change is complemented with the time-series analysis of rainfall and temperature data from Julius Nyerere International Airport Met. station and Kisarawe using Instant Statistical Software. Results indicate that households are aware of climate variability and identify indicators of climate change and variability as being decreasing rainfall trends, increasing incidences of droughts, unpredictable rainfall patterns, disappearance of wetlands and failure to predict on-set of rainy season using traditional knowledge. Households primarily attribute reduced crop yields to changes in rainfall pattern and increasing incidences of drought leading to soil moisture stress. The implications are that the agriculture dependent households are now food insecure. As a way of coping to the observed changes, the coastal communities among others have shifted to production of high value horticultural crops and use of forest resources. Nevertheless, the increased use of forest resources is threatening the existence of coastal forests and contributes to the decline of forest resources and disappearance of wildlife in the forest reserves. It is concluded that the communities studied are aware of climate issues as revealed from perceived indicators of climate variability and changes. The results from statistical analysis of 30 years climatic data are consistent with community's perception of climate variability and change. The study recommends examining the present coping strategies for the sustainability of the coastal

\footnotetext{
*Corresponding author.

How to cite this paper: Kashaigili, J.J., Levira, P., Liwenga, E. and Mdemu, M.V. (2014) Analysis of Climate Variability, Perceptions and Coping Strategies of Tanzanian Coastal Forest Dependent Communities. American Journal of Climate Change,
} 3, 212-222. http://dx.doi.org/10.4236/ajcc.2014.32020 
forests and in designing of alternative adaptive strategies such as alternative energy options, crop diversification and environmental friendly activities such as beekeeping.

\title{
Keywords
}

\author{
Adaptation, Climate Variability and Change, Coping Strategies, Coastal Communities, Perception, \\ Tanzania
}

\section{Introduction}

Climate change is cited as a complex and interdependent environmental challenge facing the world today [1] [2]. African countries including Tanzania are likely among the most world vulnerable to the impacts of climate change due to lack of inadequate adaptation capacities, economic development, and institutional capacity [3]. According to Huq et al. [4], climate change in sub-Saharan Africa may lead to decreased precipitation in semiarid to arid parts of Africa, hence leading to vulnerability and food insecurity to most of the communities. Climate change impacts have the potential to undermine and even, undo progress made in improving the socioeconomic well-being of communities. The negative impacts associated with climate change are also compounded by many factors, including widespread poverty, human diseases, and high population density, which is estimated to double the demand for food, water, and livestock forage within the next 30 years [3]. Climate change is expected to influence crop and livestock production, hydrologic balances, input supplies and other components of agricultural systems [3]. However, the nature of these biophysical effects and the human responses to them are complex and uncertain [5].

Global climate changes are expected to affect coastal communities around the world, many of which are already considered vulnerable to ongoing climatic variability [3]. The coastal zone of East Africa, including coastal parts of Tanzania such as Dar es Salaam and Coast region are not spared from the impact of climate change. While the impacts of climate change have been more evident [3], there is limited understanding on the extent of the perceptions, vulnerability and adaptive capacities of different communities such as in the coastal areas. This paper contributes to addressing these gaps based on experiences from the coastal communities. In this regard, this paper discusses local communities' perception with regard to climate variability and change based on experiences from coastal communities and complemented with the time-series analysis of rainfall and temperature from two metrological stations within the study area.

\section{Materials and Methods}

\subsection{Description of the Study Area}

The study area transcends across the administrative boundaries of Dar se Salaam and Coast Regions. It lies between longitudes $38.7^{\circ} \mathrm{E}$ and $39^{\circ} \mathrm{E}$ and latitudes $6.5^{\circ} \mathrm{S}$ to $7.08^{\circ} \mathrm{S}$. Settlements abutting the two forest reserves include the agglomeration at Pugu Kajiungeni that comprise the settlements of Pugu Kajiungeni, Mwakanga, Majohe, Buyuni and another agglomeration at Chanika. These two major settlement agglomerations are located within Dar es Salaam Region. On the part of Pwani Region, the settlements considered were Kisarawe town, and a series of settlements along Kazimzumbwi road that includes the villages of Vigama, Kazimzumbwi, Kisanga, Sungwi, Masaki and Gumba. At the centre of this area, are the two forest reserves of Kazimzumbwi and Pugu covering 53.77 and 24.19 square Kilometers respectively (Figure 1).

Topographically, the area rises from $80 \mathrm{~m}$ from east to about $750 \mathrm{~m}$ above mean sea level towards the southern slopes in Kisarawe, east of Sungwi Village that marks the southern border between Ilala and Kisarawe districts located at Dar es Salaam and Coast Regions respectively. In terms of accessibility, the Dar es SalaamManero-Mango road that passes through Kisarawe town is the main spine that links between Ilala and in Kisarawe District. The Pugu Kajiungeni-Chanika road serves the Buyuni and Chanika agglomeration with ultimate link to Chamazi settlement in Ilala.

\subsection{Methods}

A socio-economic survey was conducted in three locations in the study area (Buyuni/Majohe and Chanika in 


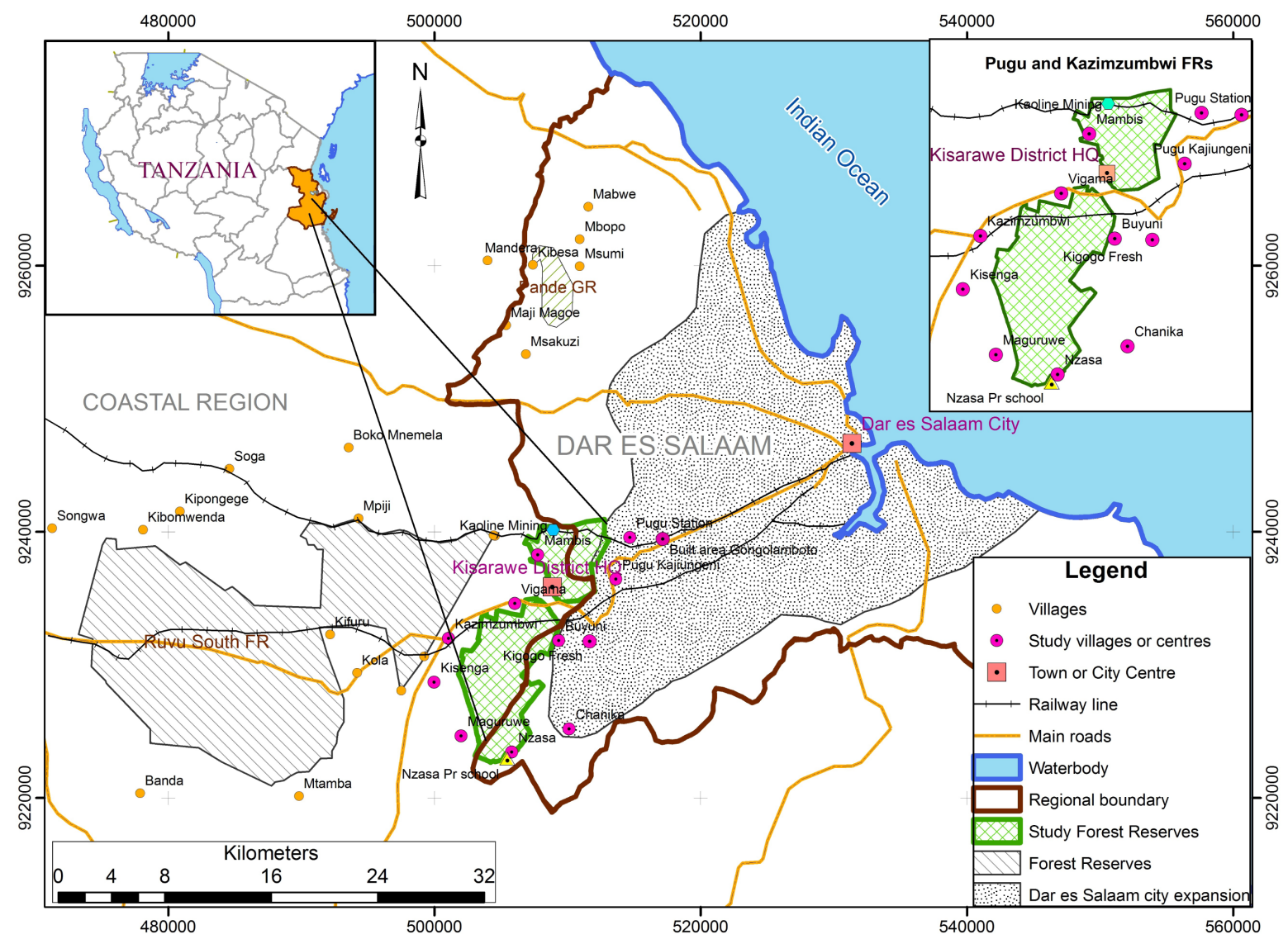

Figure 1. Map of the study area.

Ilala District and Masaki in Kisarawe District) in order to assess the community's perception of climate change and variability and their implication on coastal forest degradation as well as the communities coping strategies. Chanika and Buyuni/Majohe settlements were selected to represent the peri-urban environment for Ilala District, while Masaki was identified to represent the rural setting for Kisarawe District. Key informant interviews with agricultural extension staff in the study areas, focus group discussion and semi-structured questionnaire were used to collect socio-economic data. Focus group discussion involved about ten members from each of the study area. The members were drawn from the communities representing men, women, elderly and youths. A prepared checklist was used to guide the focus group discussions. The semi-structured questionnaire was administered to a total of 150 households representing 50 randomly selected households from each of the three study locations. SPSS and Microsoft Excel computer programs were used to analyse collected data and to characterize the socioeconomic condition of the study communities.

The questionnaire was also designed to capture perceptions of climate variability and change using the indicators of rainfall variability between seasons and years, trends in temperature increase for the past 10 years and occurrence of extreme events such as droughts and using indigenous knowledge. Perceptions of climate variability and change is complemented with the time-series analysis of annual rainfall, number of rainy days, seasonal rainfall variability and extreme events from thirty years rainfall and temperature for Julius Nyerere International Airport Met. station in Dar es Salaam and Kisarawe using Instant Statistical Software. The climatic data were collected from Tanzania Metrological Agency (TMA) in Dar es Salaam.

\section{Results and Discussion}

\subsection{Perceptions on Climate Variability and Change and Their Effects}

The communities' perceptions on climate variability and change are presented in Table 1 . The revealed indica- 
Table 1. Community’s perception of climate variability and change.

\begin{tabular}{|c|c|c|c|}
\hline Community & Community indicators of climate variability and change & $\begin{array}{l}\text { Indicators still in use for } \\
\text { determination of on-set of } \\
\text { rainfall }\end{array}$ & $\begin{array}{l}\text { Extreme events } \\
\text { observed } \\
\text { recently }\end{array}$ \\
\hline \multirow{4}{*}{ Buyuni/Masaki } & - $\quad$ Decreasing trend of rainfall (past $10 \mathrm{yr}$ ) & \multirow{13}{*}{$\begin{array}{l}\text { - Appearance of } \\
\text { certain insects } \\
\text { (Sangaugimbi, Vakule, Vikanikani) } \\
\text { - Appearance of certain plants } \\
\text { (Tindiga) } \\
\text { (T) }\end{array}$} & \multirow{9}{*}{$\begin{array}{l}\text { - } \\
\text { - } \quad \text { Floods }(1989 / 90) \\
\text { - } \quad \text { Extreme high } \\
\text { temperature }\end{array}$} \\
\hline & o Unpredictable & & \\
\hline & - Increasing incidences of droughts & & \\
\hline & Increasing food insecurity & & \\
\hline \multirow{9}{*}{ Chanika } & - $\quad$ Unpredictable rainfall patterns compared to early 1990 s & & \\
\hline & Vuli (October-December) & & \\
\hline & Masika (March-June) & & \\
\hline & - Yongwe used to be a wetland with Mzinga river & & \\
\hline & $\begin{array}{l}\text { flowing throughout the year but presently dry } \\
\text { - } \quad \text { Failure to predict onset of rain season using } \\
\text { traditional indicators and indigenous knowledge such as: }\end{array}$ & & \\
\hline & $\begin{array}{l}\text { Moon direction } \\
\text { (in the past could determine on-set of rainfall season; } \\
\text { however presently this is no longer the case) }\end{array}$ & & \multirow{2}{*}{$\begin{array}{l}\text { - Mzinga river } \\
\text { changed to seasonal } \\
\text { - } \quad \text { Disappearance of } \\
\text { Hippopotamus }\end{array}$} \\
\hline & $\begin{array}{l}\text { o Appearance of cluster of stars } \\
\text { (Kilimia and Mpini wa Kata). Stars were seen at a } \\
\text { distance around midnight. Presently they are unable to do such } \\
\text { predictions using these stars). }\end{array}$ & & \\
\hline & $\begin{array}{l}\text { o Occurrence of insects (Mzungu these normally dig down } \\
\text { on the ground, and Nyenze, normally found above the ground). } \\
\text { These insects are no longer available in the study areas. }\end{array}$ & & \\
\hline & $\begin{array}{l}\text { o Appearance of certain types of clouds. These were used } \\
\text { to provide an indication of short or long rains, but } \\
\text { presently they are no longer seen during the daylight. }\end{array}$ & & \\
\hline
\end{tabular}

tors of climate variability and change include decreasing rainfall, increasing incidences of droughts, unpredictable rainfall patterns, disappearance of wetlands and failure to predict the on-set of rainy season using traditional indicators and indigenous knowledge.

Communities in Buyuni reported to have experienced decrease of rainfall pattern for the past ten years. Before 2003, they used to receive good short rains (Vuli) between October and December and long rains (Masika) between March and June, but presently Vuli rains have almost completely disappeared and Masika rains comes late (until April for some years) and stops earlier. In Chanika, communities reported to experience difficulty in determining the on-set of rainfall using local or indigenous knowledge compared to 1980s and 1990s as revealed in (Table 1). In the past, local indicators such as the moon direction, the appearance of cluster of stars (Kilimia and Mpini wa Kata), occurrence of insects (Mzungu and Nyenze) and appearance of a certain type of clouds were being used to determine the on-set of rainfall season, however, presently these are no longer possible.

Only few indicators such as appearance of some insects (Sangaugimbi, Vakule, Vibaruti, Vikanikani) and plants (Tindiga) are still in use to locally forecast the rainfall season. Apart from unpredictable rainfall patterns, extreme events such as heavy storms and flooding have been noted. Also Mzinga River which was perennial has become seasonal resulting into disappearance of hippopotamus, fish and increased river sedimentation. Changes in rainfall pattern, particularly drought have considerably affected agriculture production in the study communities due to soil moisture stress. As a result of increasing rainfall variability, agriculture dependent households are now food insecure.

Communities are experiencing livelihood challenges that include declining agricultural production of traditional crops such as cassava, groundnuts, maize and passion fruits, increased crop diseases and declining soil fertility among other causes.

\subsection{Rainfall and Temperature Variability and Trends Using Climatic Data}

To confirm community's perception on climate variability and change in the study area, statistical analysis of 30 years rainfall and temperature records for Julius Nyerere International Airport Met. Station in Dar es Salaam and Kisarawe climatic station was made. The historical analysis of 30 years rainfall data from Julius Nyerere Inter- 
national Airport and Kisarawe Met. stations, indicate clear decadal climate variability. The seasonal rainfall and the total number of seasonal rain days for Julius Nyerere International Airport and Kisarawe indicate declining trend (Figures 2-5). For example, in the most recent decade (2000-2010), the total number of seasonal rain days has decreased respectively with more changes occurring in short rains (Vuli). This implies that there is a strong decadal variability of rainfall across the study areas with a decreasing trend. This is confirmed by statistical analysis on slopes of trend line at $95 \%$ of significance for seasonal rainfall and annual rainfall. The slopes of the trend line revealed to be significantly decreasing (Table 2), meaning that the rainfall amount has consistently been decreasing over the time. Further analysis of mean monthly rainfall reveals the shifts in peaking and timing of rainfall (Figure 6 and Figure 7).

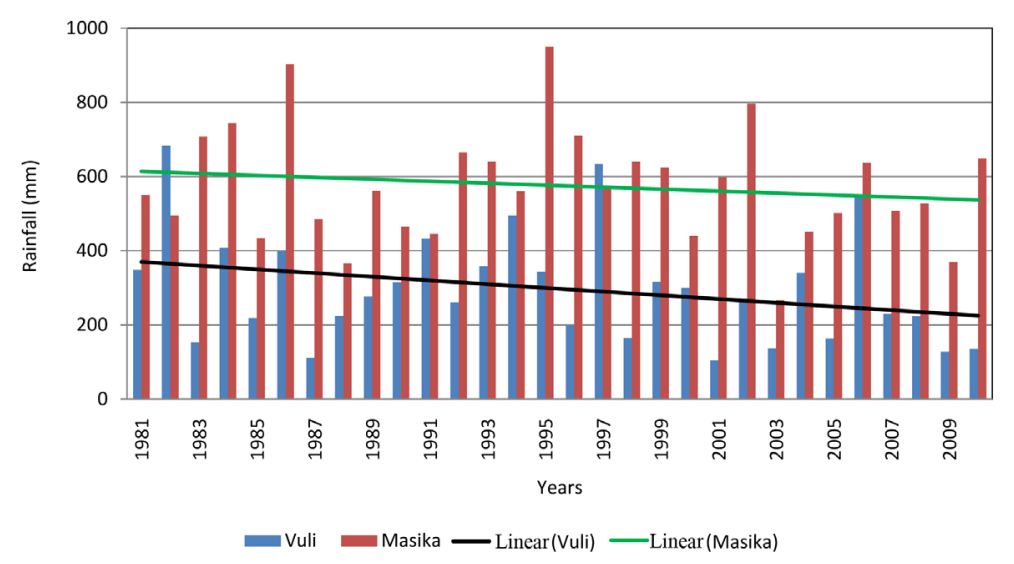

Figure 2. Seasonal rainfall Vuli and Masika for Julius Nyerere International Airport Met. station in Dar es Salaam (1981-2010) fitted with a linear trend line.

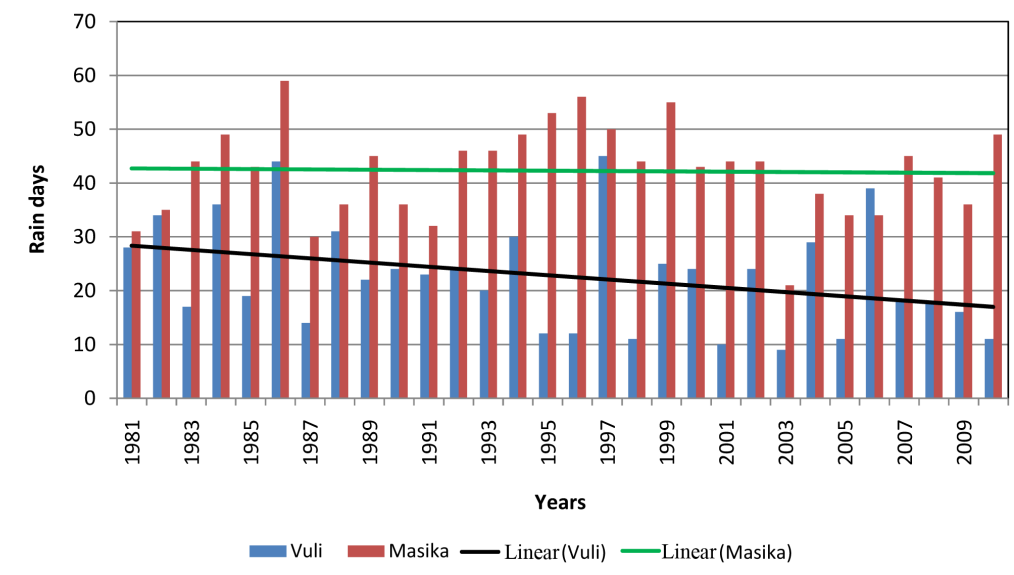

Figure 3. Rain days for Vuli and Masika seasons for Nyerere International Airport Met. station in Dar es Salaam (1981-2010) fitted with a linear trend line.

Table 2. Summary of test statistic (Z) in seasonal and annual rainfall amounts.

\begin{tabular}{|c|c|c|c|c|c|c|c|}
\hline \multirow{2}{*}{ Station } & \multicolumn{2}{|c|}{ Record length } & \multicolumn{5}{|c|}{ Seasonal Trends } \\
\hline & & To & Short rains (SON) & Intermediate season (DJF) & Long rains (MAM) & Dry season (JJA) & ANN \\
\hline Julius Nyerere Int. airport & 1980 & 2009 & -0.642 & -1.032 & -0.469 & -2.232 & -2.045 \\
\hline Kisarawe Met. station & 1980 & 2009 & -1.784 & -1.219 & -0.994 & -1.895 & -2.007 \\
\hline
\end{tabular}




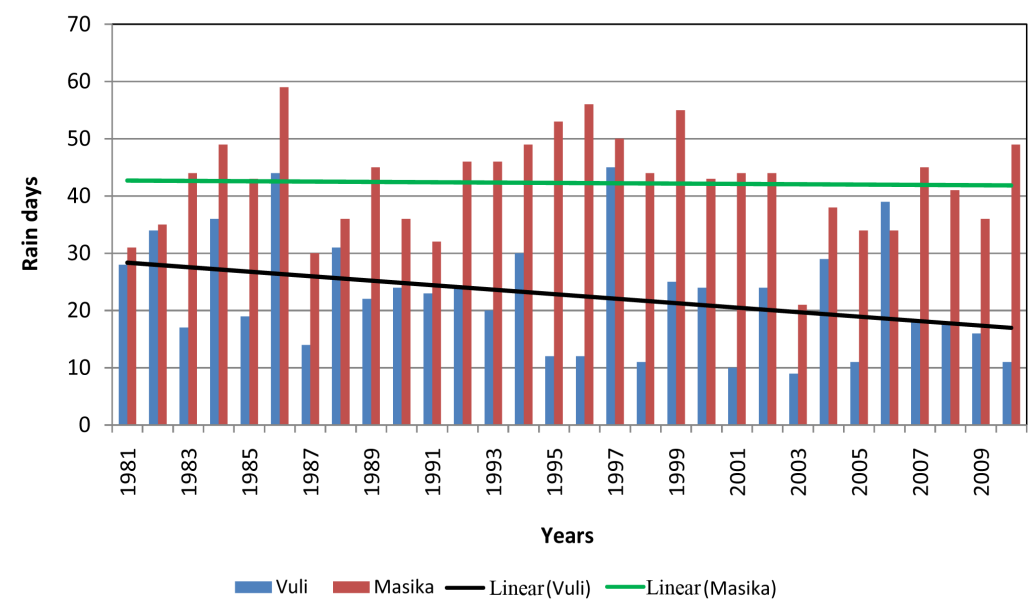

Figure 4. Seasonal rainfall Vuli and Masika for Nyerere International Airport Met. station in Dar es Salaam (1981-2010) fitted with a linear trend line.

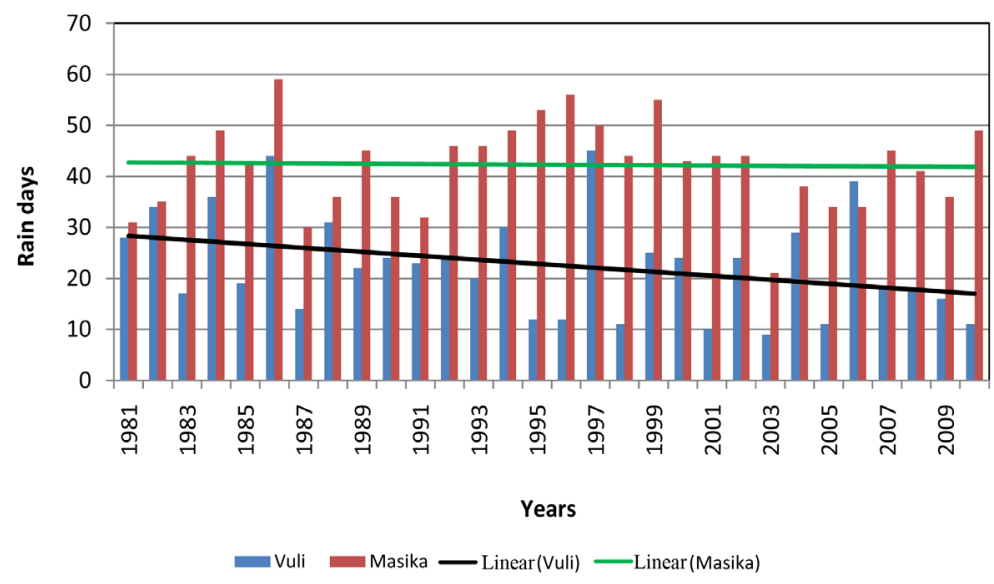

Figure 5. Rain days for Vuli and Masika seasons for Kisarawe Met. station (1981-2010) fitted with a linear trend line.

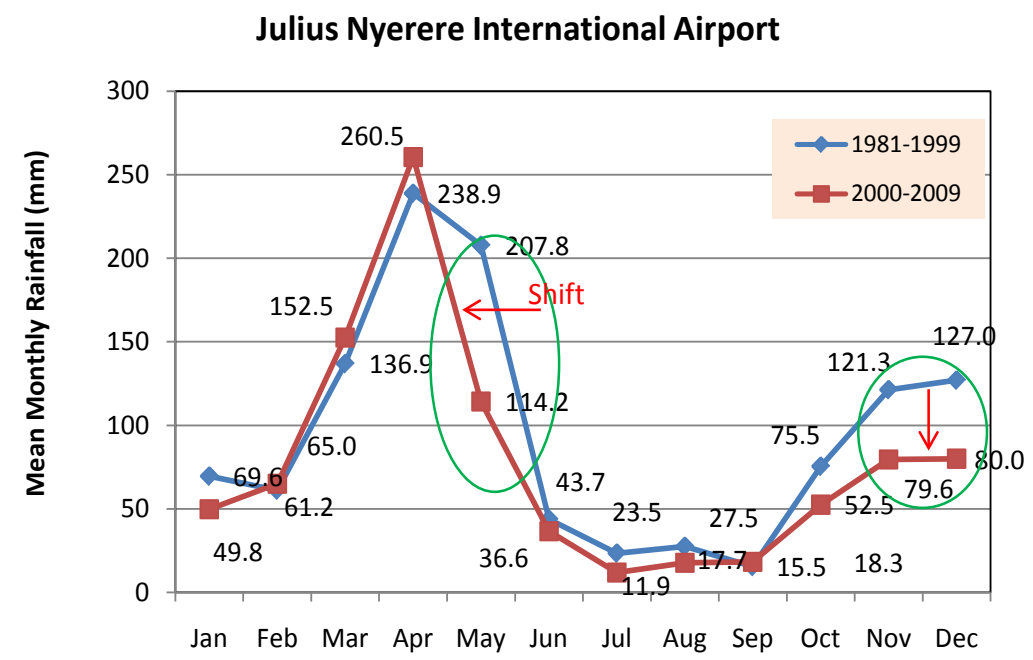

Figure 6. Shifts and change in magnitude of mean monthly rainfall amounts for Nyerere International Airport Met. station. 


\section{Kisarawe Met. Station}

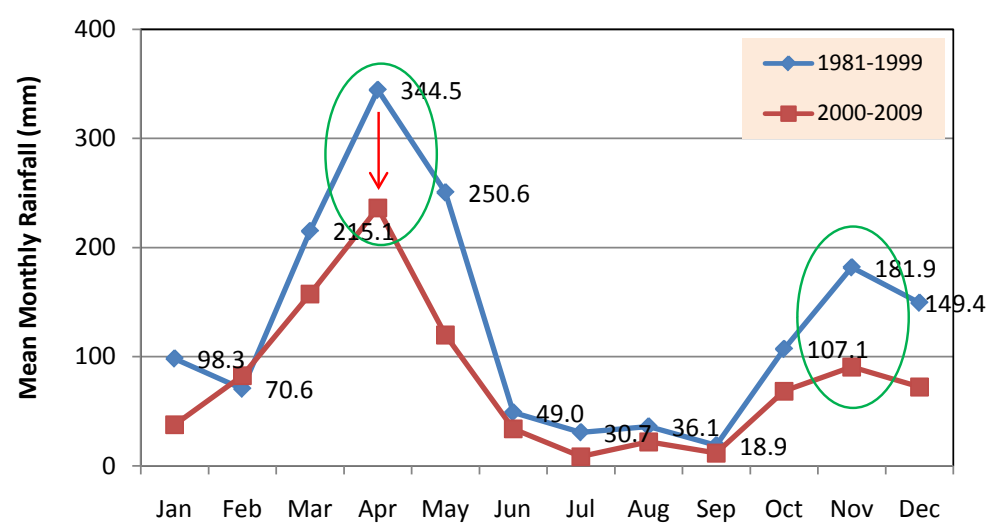

Figure 7. Shifts and change in magnitude of mean monthly rainfall amounts Kisarawe Met. stations.

Analysis of seasonal rainfall records also shows strong seasonal variability of rainfall pattern within the study sites, both for Vuli and Masika seasons (Figures 8-10). For example, there is a reduction of up to $200 \mathrm{~mm}$ of seasonal rainfall (Vuli and Masika rains) for both locations in the period of 30 years. More analysis of total rainfall by seasons for Kisarawe and Julius Nyerere International Airport Met. station indicate negative trends for both Vuli and Masika. Vuli rainfall displays more variability than Masika rains, and this poses greater risks to farmers who depend on Vuli rains for crop production. The risks is likely to induce up to 30\% crop failures (on average one year in every three years receives Vuli rainfall less than $100 \mathrm{~mm}$ ). Analysis of time series of temperature records for Julius Nyerere International Airport and Kisarawe weather stations indicate evidence of climate change with increasing trends of both mean minimum and maximum temperature and this is consistent with the period of declining rainfall. The trend for the mean maximum temperature shows that the coastal areas have warmed by almost two degrees for the past 30 years (Figure 11). However, a strong annual and decadal variability for both mean maximum and minimum temperature with an increasing trend is shown by trend lines (Figure 7 and Figure 8).

Extreme temperature events constitute climate variability and change. Such extreme temperature events are observed from the analysis of temperature extremes for Julius Nyerere International Airport for 30 years. Temperature greater than 35 degrees is not common for Dar es Salaam and is described as an extreme event. The analysis shows that most of the temperature greater than 35 degrees in the region coincides with the cropping seasons of Masika (Figure 12). Such coincidence could accelerate drought spells and contribute to crops failure. The temporal distribution of maximum temperature greater than 35 degrees has increased in the recent decade (Figure 13).

For the first decade $(1$ - 10) from 1981 to 1990 maximum temperature events were only five. In the next decade (1990-2000) the events increased to six, and they have reached to 8 cases in the recent decade ending 2010.

\subsection{Coping and Adaptation Strategies by the Coastal Forest Dependent Communities}

Irrespective of the motivation for adaptation, either purposeful or unintentional adaptations can generate short-term or long-term benefits [6]. Adaptation to climate change requires that farmers first notice that the climate has changed, and then identify useful adaptation strategies and implement them [7]. This study has confirmed peoples' perceptions that climate is variably changing and many effects have been realized including drying of perennial rivers, declining agricultural production of traditional crops, increased crop diseases and declining soil fertility among others. In coping with declining soil productivity, people noted that it is increasingly becoming difficult to obtain good crop harvest without using farm manure. However, prolonged use of chemical fertilizers was reported to contribute to degradation of land; hence it is no longer practiced. Considering decline in agricultural production, farmers are shifting to production of high value horticultural crops and have taken the advantage of urban demands on the vegetables. Also dependency on forest resources was reported to have increased, a factor which contribute to decline of forest resources and disappearance of wildlife in the forest re- 

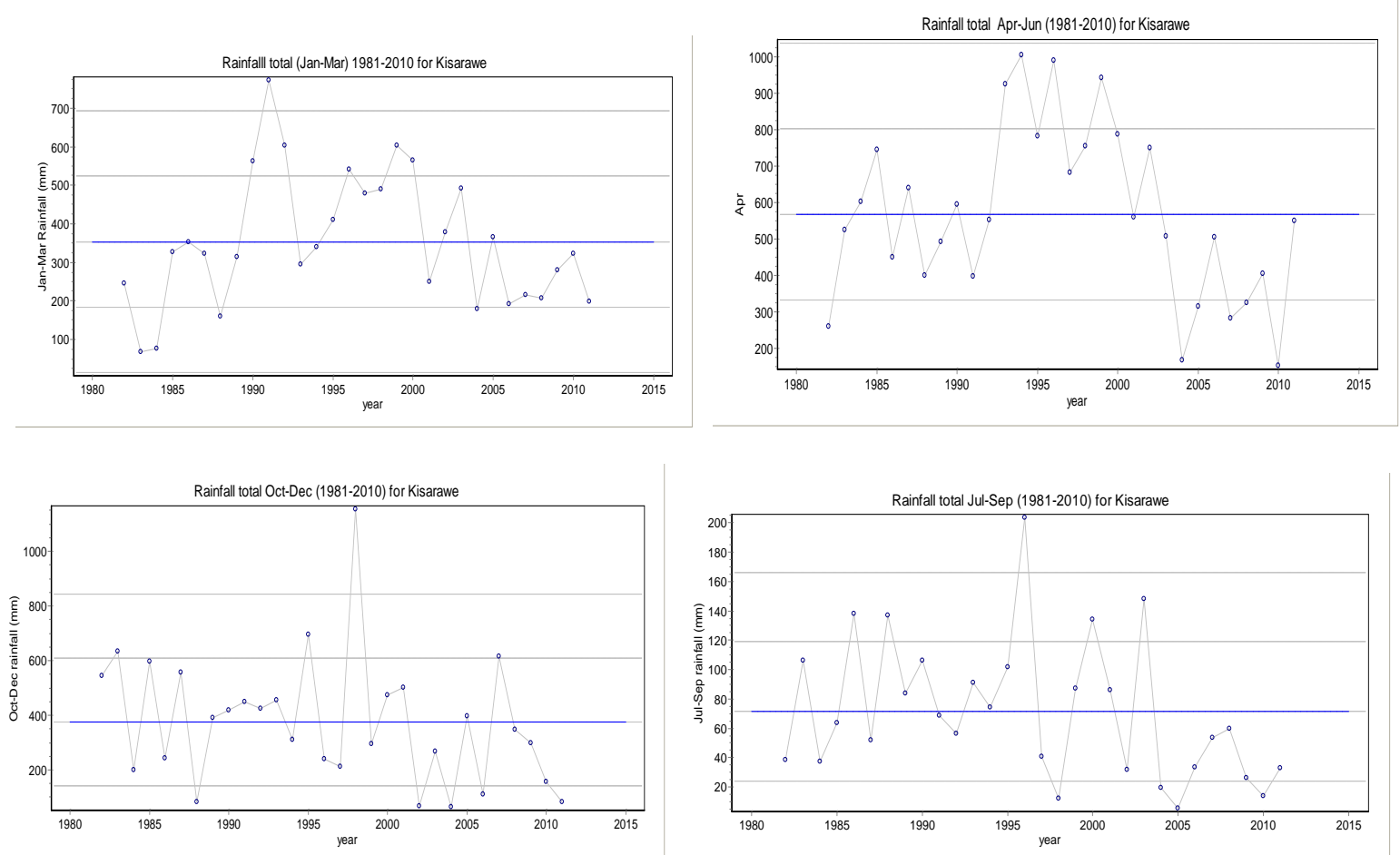

Figure 8. Seasonal total rainfall variability at Kisarawe Met. station (1981-2010).
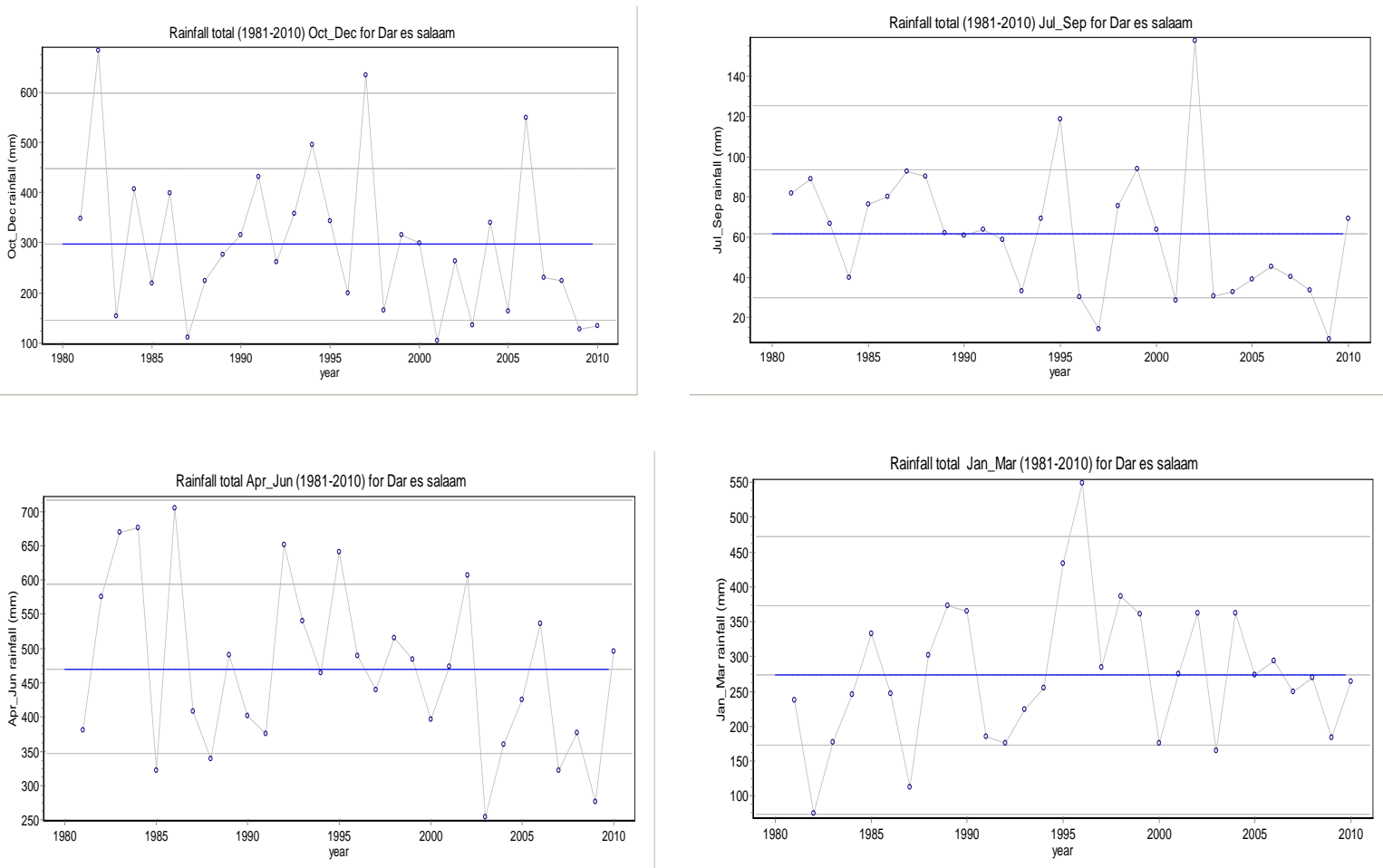

Figure 9. Seasonal total rainfall variability at Dar es Salaam Airport Met. station (1981-2010).

serves. For example $46 \%$ and $17 \%$ of the respondents in Buyuni and Chanika reported to depend on forest resources for firewood and charcoal respectively. Other forest products which communities depend on include 

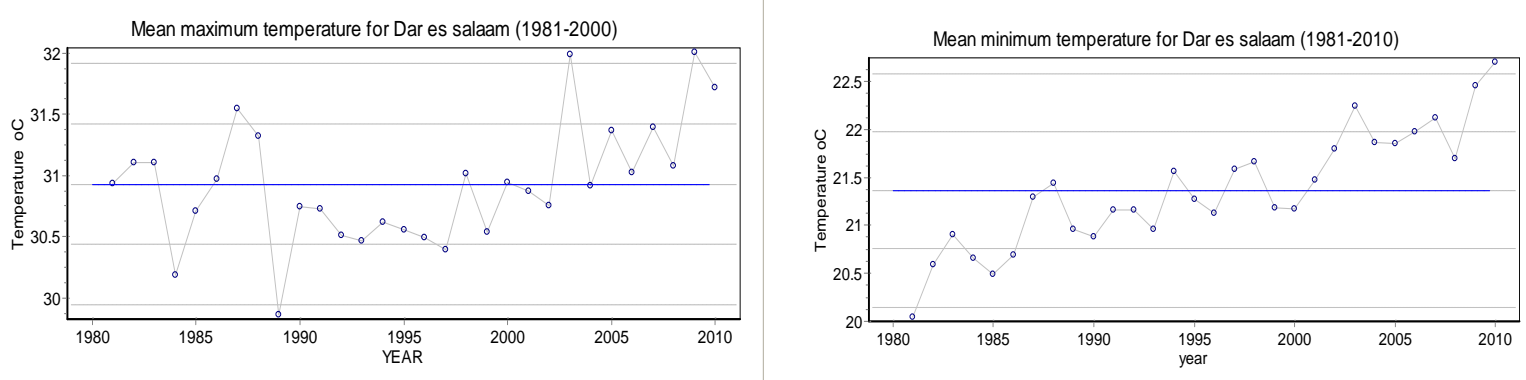

Figure 10. Variability in mean minimum and maximum temperature at Julius Nyerere International Airport Met. station in Dar es Salaam (1981-2010).

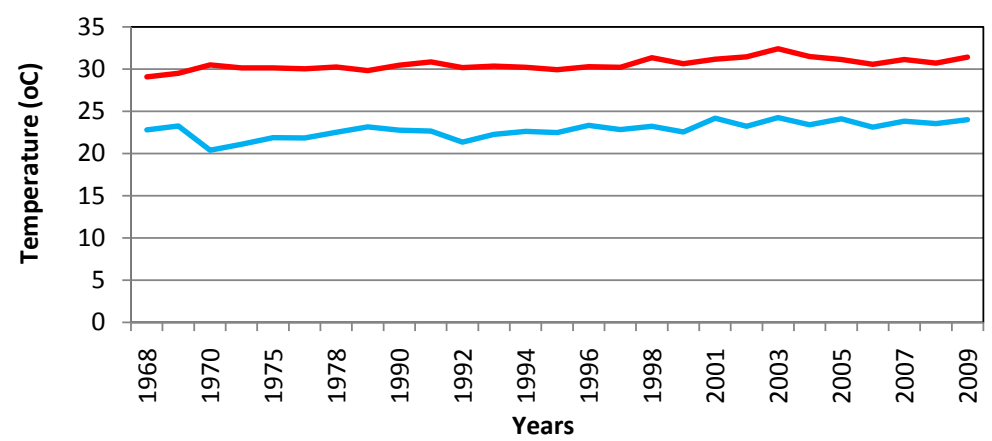

-Mean-max Temp. —Mean-min Temp.

Figure 11. Variability in mean minimum and maximum temperature at Kisarawe Met. station (1968-2009).

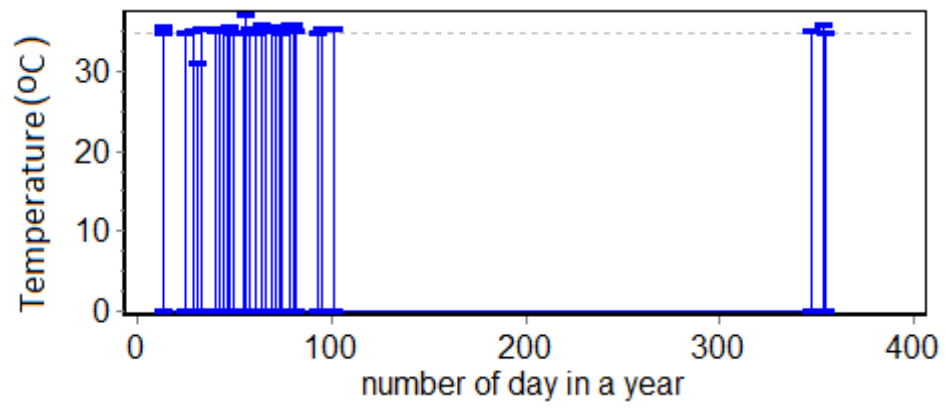

Figure 12. Maximum temperature peaks over $35^{\circ} \mathrm{C}$ at Julius Nyerere International Airport Met. station in Dar es Salaam (1981-2010).

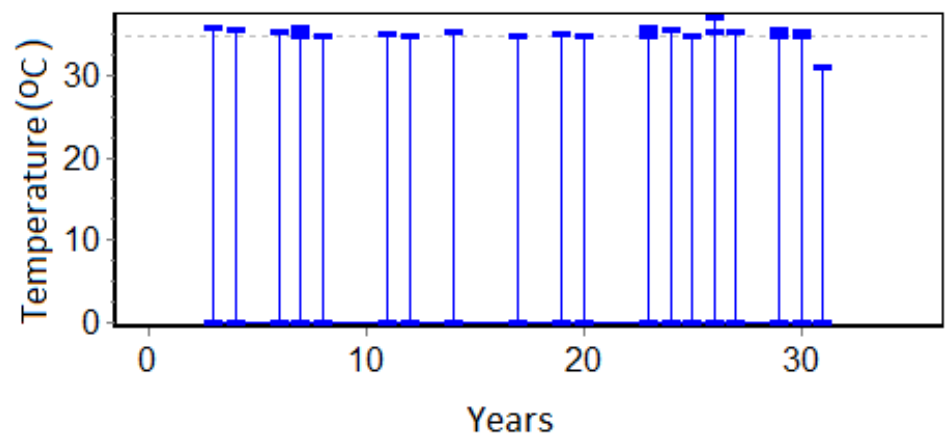

Figure 13. Temporal distribution of temperature peaks over $35^{\circ} \mathrm{C}$ at $\mathrm{Ki}$ sarawe (1981-2010). 
wild fruits, mushrooms, building poles and fodder for livestock. It is apparent that some of the adaptive strategies such as charcoaling are not sustainable and can lead to other multiple effects on the environment and contribute to climate variability and change. A study by Kashaigili et al. [8] revealed that for the periods 1980-1995 and 1995-2010, closed forest cover in Pugu Forest Reserve decreased by 4.5\% and 25.3\% respectively, while for Kazimzumbwi Forest Reserve, the closed forest cover decreased by $11.9 \%$ and $31.3 \%$ respectively. Among the key drivers for the changes is the charcoal business [9]. Considering that climate change impacts are already being felt, interventions aimed at reducing negative impacts and risks are required [10].

\section{Conclusion}

Observed climate variability and change from the statistical analysis of 30-year records of rainfall and temperature for Julius Nyerere International Airport and Kisarawe weather stations are consistent with community's perception of climate change and variability. According to the communities, climatic changes and variability are identified by declining rainfall amount, increasing rainfall variability, increasing temperature over the last ten years, drying of cassava crop, and increased incidence of diseases pests for crops and livestock. Other indicators include disappearance of wetlands and failure to predict on-set of rainy season using traditional knowledge. The implications are that the agriculture dependent households are food insecure. As a way of coping and adapting to the observed changes, the coastal communities among others have shifted to production of high value horticultural crops and use of forest resources. Nevertheless, the increased use of forest resources is threatening the existence of coastal forests and contributes to the decline of forest resources and disappearance of wildlife in the forest reserves. The study recommends examining the present coping strategies for the sustainability of the coastal forests and in designing of alternative adaptive strategies such as alternative energy options, crop diversification and environmental friendly activities such as beekeeping.

\section{Acknowledgements}

This research was supported by a NORAD funded research programme-Climate Change Impacts, Adaptation and Mitigation (CCIAM) of the Sokoine University of Agriculture through Analysis of the Impacts of Urban Land Use and Climate Change on Coastal Forest Eco-system and Management research project.

\section{References}

[1] Clark, W., Mitchell, R., Cash, D. and Alcock, F. (2002) Information as Influence: How Institutions Mediate the Impacts of Scientific Assessments on Global Environmental Affairs. John F. Kennedy School of Government, Harvard University, Faculty Research Working Papers Series.

[2] Obasi, G.P. (1997) Climate Change and Freshwater Management. World Meteorological Organization. 1st World Water Forum, Marrakech.

[3] Intergovernmental Panel on Climate Change (IPCC) (2007) Climate Change 2007-Impacts, Adaptation and Vulnerability. Contribution of Working Group II to the Fourth Assessment Report of the IPCC. Intergovernmental Panel on Climate Change.

[4] Huq, S., Rahman, A., Konate, M., Sokona, Y. and Reid, H. (2003) Mainstreaming Adaptation to Climate Change in Least Developed Countries (LDCs). www.un.org/special-rep/ohrlls/ldc/LDCsreport.pdf

[5] Apata, T.G., Samuel, K.D. and Adeola, A.O. (2009) Analysis of Climate Change Perception and Adaptation among Arable Food Crop Farmers in South Western Nigeria. Contribution Paper Prepared for Presentation at the International Association of Agricultural Economists 2009 Conference, Beijing, 16-22 August 2009.

[6] Adger, W.N., Arnell, N.W. and Tompkins, E.L. (2005) Successful Adaptation to Climate Change across Scales. Global Environmental Change Part A, 15, 77-86. http://dx.doi.org/10.1016/j.gloenvcha.2004.12.005

[7] Maddison, D. (2006) The Perception of and Adaptation to Climate Change in Africa. CEEPA Discussion Paper No. 10. Centre for Environmental Economics and Policy in Africa, University of Pretoria, Pretoria.

[8] Kashaigili, J.J., Mdemu, M.V., Nduganda, A.R. and Mbilinyi, B.P. (2013) Integrated Assessment of Forest Cover Change and Above-Ground Carbon Stock in Pugu and Kazimzumbwi Forest Reserves, Tanzania. Advances in Remote Sensing, 2, 1-9. http://dx.doi.org/10.4236/ars.2013.21001

[9] Mdemu, M., Kashaigili, J.J., Lupala, J., Levira, P., Liwenga, E., Nduganda, A. and Mwakapuja, F. (2012) Dynamics of Land Use and Land Cover Changes in the Pugu and Kazimzumbwi Forest Reserves. Proceeding of the 1st Climate 
Change Impacts, Mitigation and Adaptation Programme Scientific Conference, Dar es Salaam, 2-3 January 2012, 54-77.

[10] Kashaigili, J.J., Rajabu, K. and Masolwa, P. (2009) Freshwater Management and Climate Change Adaptation: Experiences from the Great Ruaha River Catchment in Tanzania. Climate and Development, 1, 220-228.

http://dx.doi.org/10.3763/cdev.2009.0025 
Scientific Research Publishing (SCIRP) is one of the largest Open Access journal publishers. It is currently publishing more than 200 open access, online, peer-reviewed journals covering a wide range of academic disciplines. SCIRP serves the worldwide academic communities and contributes to the progress and application of science with its publication.

Other selected journals from SCIRP are listed as below. Submit your manuscript to us via either submit@scirp.org or Online Submission Portal.
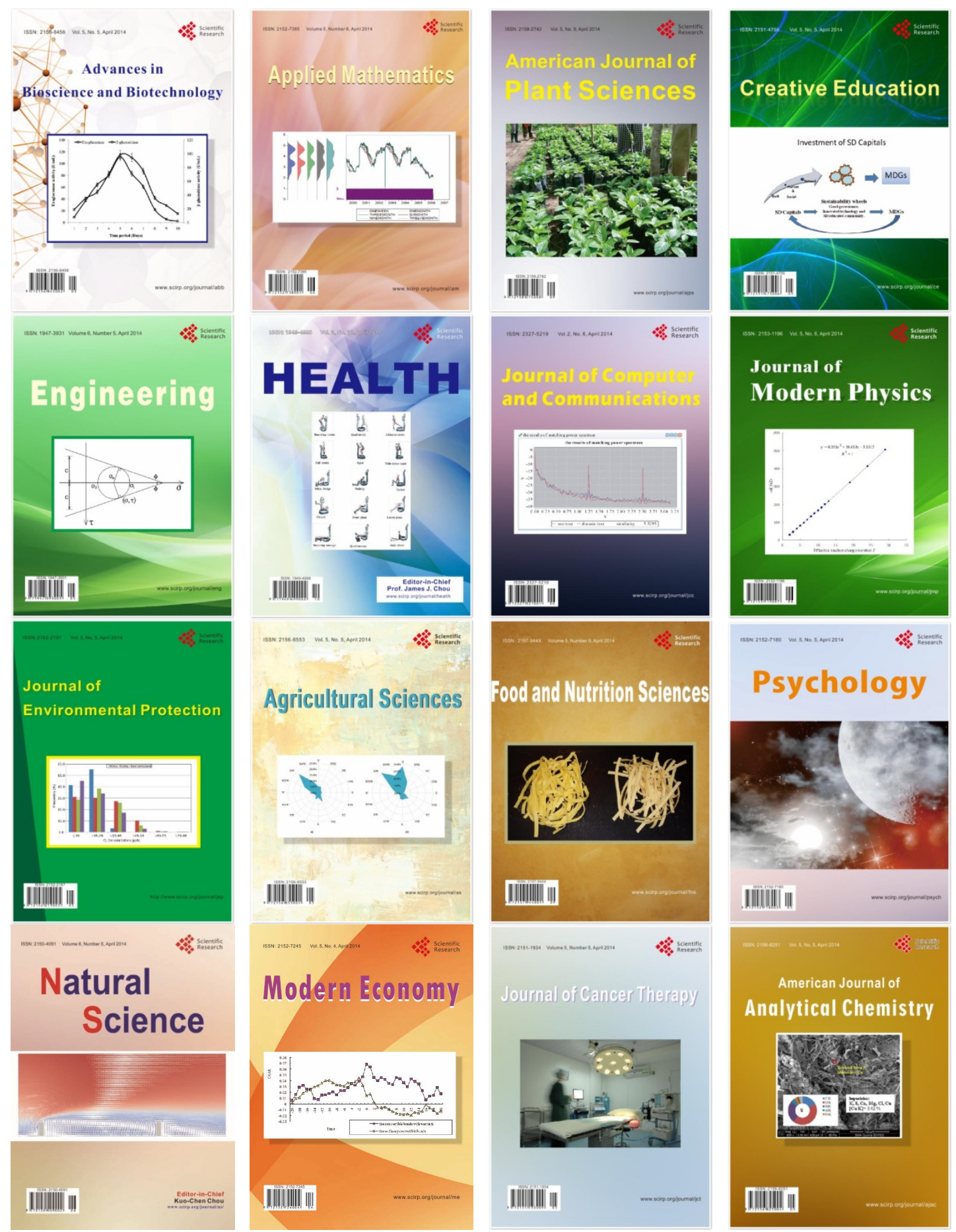